Canadian University Music Review

Canadian University Music Review

Revue de musique des universités canadiennes

\title{
With a Song in Her Heart: A Celebration of Canadian Women Composers Through Performance and Discussion: University of Windsor, Ontario, 11-12 March 1994
}

\section{Edward Kovarik}

\author{
Numéro 15, 1995
}

URI : https://id.erudit.org/iderudit/1014397ar

DOI : https://doi.org/10.7202/1014397ar

Aller au sommaire du numéro

Éditeur(s)

Canadian University Music Society / Société de musique des universités canadiennes

ISSN

0710-0353 (imprimé)

2291-2436 (numérique)

Découvrir la revue

Citer ce compte rendu

Kovarik, E. (1995). Compte rendu de [With a Song in Her Heart: A Celebration of Canadian Women Composers Through Performance and Discussion: University of Windsor, Ontario, 11-12 March 1994]. Canadian University Music Review / Revue de musique des universités canadiennes, (15), 154-156.

https://doi.org/10.7202/1014397ar

All Rights Reserved (C Canadian University Music Society / Société de musique des universités canadiennes, 1995
Ce document est protégé par la loi sur le droit d'auteur. L'utilisation des services d'Érudit (y compris la reproduction) est assujettie à sa politique d'utilisation que vous pouvez consulter en ligne.

https://apropos.erudit.org/fr/usagers/politique-dutilisation/ 


\section{CONFERENCE REPORTS/ COMPTES RENDUS DE COLLOQUES}

\section{With a Song in Her Heart: A Celebration of Canadian Women Composers Through Performance and Discussion University of Windsor, Ontario 11-12 March 1994}

\section{Edward Kovarik}

Prompted by a recent spate of publications and by several similar conferences in the United States, the Windsor conference offered a unique look at the Canadian experience of women composers, past and present, and provided in addition an object lesson in interdisciplinary cooperation. Conference speakers came from across Ontario and beyond, and members of the audience came from as far away as Texas and the United Kingdom.

The Conference kick-off was a Friday night concert by the Windsor Symphony honouring one of the grande dames of Canadian music, Barbara Pentland. Two of Pentland's larger works were featured: the well-known Symphony for Ten Parts and the contemporary, but lesser-known, Concerto for Piano and Strings, with the solo part played by Philip Adamson, a faculty member at the University of Windsor. Preceding the concert were brief talks on Pentland's piano music by Thora duBois, a Canadian-born pianist now teaching at Oklahoma State University, and on preparing Pentland's works for performance by Susan Haig, Music Director of the Windsor Symphony.

The main sessions of the Conference began on Saturday morning with two groups of papers, one by scholars and a second by practising composers. The opening session was titled "The Other Side of Silence: Issues in Women's Music." Virginia Caputo, a doctoral candidate in social anthropology at York University, discussed the creation of "canons of masterworks" and the gender bias inherent in this process. Marie-Thérèse Lefebvre, professor of music at the Université de Montréal and author of La création musicale des femmes au Québec (1991), outlined the work of a number of younger Quebec women composers. While noting that music itself is without gender, she proposed a definition of "feminist music" as music associated with feminist texts or used in combination with other media (dance, painting) to give symbolic representation 
to women's issues. Geraldine Finn, professor of cultural studies at Carleton University, suggested that the social organization of musical activity in Western culture reflects a deep-lying power structure which works to subordinate women. She noted that the first half of Collins Encyclopedia of Music includes among its entries the names of over a hundred and twenty women, but half of these are in fact the names of operas and nearly a third more are sopranos (no competition there). The handful of composers listed are all hyphenated: "pianist-composer," "soprano-composer," etc. Elaine Keillor, pianist-scholar and professor of music at Carleton University, asked “Are we really 'minorish'?" She pointed out that gender-based labels attached to cadences, themes, and other musical procedures have little purpose other than to perpetuate sexual stereotypes.

The second session, titled "Ourselves, Our Work: The Composer's Perspective," presented a fascinating variety of views and experiences. Carol Ann Weaver, professor of music at the University of Waterloo, exposed the paradox of women composers who are hesitant about creating "consciously feminine" music while their male colleagues have no qualms about expressing their feminine side. Her solution: the personal expression of feminine experience. As models and inspiration she offered some examples of women's music in nonWestern cultures. Mary Gardiner, well known as an activist and publicist for women's music, outlined her career as a "late-blooming" composer (due to a lack of role models in her youth) and described her association with the Ardeliana Trio of Toronto. Andra McCartney, a graduate student in ethnomusicology at York University, related her experiences inside the macho world of the electroacoustic studio, where the language is dominated by male-oriented imagery: "punch," "grab," etc. Elma Miller, of Burlington, Ontario, touched impressionistically on many matters of practical concern, including how contemporary composers are categorized by conductors, juries and arts councils, and the many reasons that can be found for not picking a given work or composer; to counter this mind-set, she believes, political activism is required.

Luncheon was highlighted by the keynote address of Elaine Keillor, who reviewed the recent literature on feminist theory, discussed the social power structure underlying conventional music making, and noted that a number of nineteenth-century Canadian women musicians "moved beyond the boundaries normally accepted" in their time. Keillor believes that the opportunities afforded women like Frances Moore and Eva York in the last century were due in part to the frontier nature of Canadian society, and that with the coming of modern times some of these opportunities have been lost.

The centrepiece of the afternoon sessions was a series of pictorial vignettes: scenes from the lives of three Canadian composers of the past re-created by student actresses from the University of Windsor's School of Dramatic Art. The 
subjects, Sophie Eckhardt-Gramatté, Mary Travers ("La Bolduc"), and Gena Branscombe, were chosen to reflect a broad spectrum of personal experience and musical idiom: the passionate commitment of Eckhardt-Gramatté, the earthiness of Bolduc, the intellectualism of Branscombe. The scripts were compiled by the students themselves as part of a class project, and each dramatic scene was followed by a performance of the composer's music.

To conclude the scheduled activities a round table of all the speakers fielded questions and comments from the floor, including the relation of some personal experiences with Pentland and Eckhardt-Gramatté. The papers of the Conference are to be published by the Humanities Research Group of the University of Windsor as part of their series: "Working Papers in the Humanities."

\section{The Canadian Society for Eighteenth-Century Studies/La société canadienne d'étude du dix-huitième siècle}

Saskatoon, Saskatchewan

13-16 October 1994

\section{Paul F. Rice}

The twentieth conference of this society was held at the Delta Bessborough Hotel in Saskatoon from 13-16 October 1994, under the sponsorship of the University of Saskatchewan. The task of organizing this complex event was intrusted to the capable hands of Alex Sokalski (Conference President) and PeterLoptson (VicePresident) who, along with a large team of able volunteers, oversaw the smooth running of four simultaneous sessions of papers. Delegates attended from France, Spain, Canada and the United States.

The theme of the conference was "Reason and Unreason/raison et déraison". In addition to four plenary sessions, 102 individual papers were delivered, with topics that explored a wide range of interests in the social, political, artistic and scholarly pursuits of eighteenth-century life. The interdisciplinary nature of this society was reflected in sessions that ranged from the "History of Science" to "Gardens, Symbolic Space and Pope" and from "Pornography and Pornographers" to "The German Enlightenment". Four music papers presented aspects of eighteenth-century musical life within a socio-historical context: (1) J. Richard Raum (University of Regina) "18th-Century Society and the Professional Musician: Thomas Geschladt, A Case History," (2) Paul F. Rice (Memorial University of Newfoundland) "Power, Politics and the Production of Opera: Madame de Pompadour, Mondonville and Rameau," (3) Gordana Lazarevich 